\title{
MATERIALS RESEARCH SOCIETY
}

\author{
2019 Board of Directors \\ Officers \\ Michael R. Fitzsimmons, President \\ Sean J. Hearne, Past President \\ Matt Copel, Vice President \\ Eric A. Stach, Secretary \\ David J. Parrillo, Treasurer \\ Todd M. Osman, Executive Director
}

\author{
Directors \\ Monica Jung de Andrade \\ Griselda Bonilla \\ Li-Chyong Chen \\ Dawnielle Farrar-Gaines \\ Sharon C. Glotzer \\ Claudia Gutiérrez-Wing \\ Sarah Heilshorn \\ Frances A. Houle \\ Sergei V. Kalinin
}

\author{
Kisuk Kang \\ Lincoln Lauhon \\ Paul C. Mclntyre \\ Christopher Schuh \\ Rachel Segalman \\ Molly M. Stevens \\ Yusheng Zhao \\ Ehrenfried Zschech
}

\section{Publications Committee}

\author{
S.P. Baker, Chair
}

W. Weber, Editors Subcommittee

A.J. Hurd, New Publication Products Subcommittee

R.J. Nemanich, Publications Quality Subcommittee

\section{MRS Committee Chairs}

\author{
S. Mathur, Academic Affairs \\ J. L. MacManus-Driscoll, Awards \\ D. P. Norton, Government Affairs \\ T. Aselage, Meetings
}

\section{MRS Headquarters}

T.M. Osman, Executive Director

J.A. Dillen, Director of Finance and Administration

D. Dozier, Director of Government Affairs

P.A. Hastings, Director of Meeting Activities

E.M. Kiley, Director of Communications

\section{About the Materials Research Society}

The Materials Research Society (MRS) is a not-for-profit scientific association founded in 1973 to promote interdisciplinary goal-oriented basic research on materials of technological importance. Membership in the Society includes over 14,500 scientists from industrial, government, and university research laboratories in the United States and abroad.

The Society's interdisciplinary approach to the exchange of technical information is qualitatively different from that provided by single-discipline professional societies because it promotes technical exchange across the various fields of science affecting materials development. MRS sponsors three major international annual meetings encompassing many topical symposia, as well as numerous single-topic scientific meetings each year. It recognizes professional and technical excellence, conducts tutorials, and fosters technical exchange in various local geographical regions through Section activities and Student Chapters on university campuses.

Disclaimer: Authors of each article appearing in this Journal are solely responsible for all contents in their article(s) including accuracy of the facts, statements, and citing resources. Facts and opinions are solely the personal statements of the respective authors and do not necessarily represent the views of the editors, the Materials Research Society, or Cambridge University Press.

MRS publishes numerous publications on current scientific developments. MRS Advances publishes snapshots of work in progress; article scope offers a focused, in-depth look at key
S.M. Haile, Member Engagement

E. Kupp, Public Outreach

S.P. Baker, Publications materials topics of current interest. The Journal of Materials Research publishes the latest advances about the creation of new materials and materials with novel functionalities, fundamental understanding of processes that control the response of materials, and development of materials with significant performance improvements relative to state of the art materials. MRS Bulletin provides comprehensive overviews of specific materials themes along with industry and policy developments, as well as MRS and materials community news and events. Review articles are accepted by proposal or invitation. MRS Energy \& Sustainability publishes reviews,

commentaries, and perspectives on key topics in materials research and development as they relate to energy, sustainability, and objective application of economic, sociological and governmental models, enabling research and technological developments. Articles are accepted by proposal or invitation.

MRS Communications is a high-impact journal focusing on rapid publication of completed research with broad appeal to the materials community.

MRS is an Affiliated Society of the American Institute of Physics and participates in the international arena of materials research through associations with professional organizations such as the International Union of Materials Research Societies.

For further information on the Society's activities, contact MRS Headquarters, 506 Keystone Drive, Warrendale, PA 15086-7573; telephone (724) 779-3003; fax (724) 779-8313. 
A publication of the

Mrs Communications

MRS $\begin{gathered}\text { MATERIALS RESEARCH SOCIETY } \\ \text { Advancing materials. Improving the quality of life. }\end{gathered}$ 